\title{
Plasmid-coded DNA fragment developed as a specific gene probe for the identification of enteroaggregative Escherichia coli
}

\author{
CHITRITA DEBROY*, B. D. BRIGHT†, R. A. WILSON, JEANNE YEALY, R. KUMAR† and M. K. BHAN $\dagger$ \\ Department of Veterinary Science, Pennsylvania State University, University Park, PA 16802, USA and †Department \\ of Microbiology, All India Institute Medical Sciences, New Delhi, India
}

\begin{abstract}
Summary. Enteroaggregative Escherichia coli $(\mathrm{EAggEC})$ is a recently discovered diarrhoeal pathogen implicated as a cause of persistent diarrhoea in children. EAggEC strains exhibit a characteristic pattern of adherence when incubated with HEp-2 cells. Because of the difficulty in identifying this group of bacteria, the epidemiological significance of this pathogen as a diarrhoeal agent has not been fully realised. A gene probe was developed from the $60-\mathrm{MDa}$ plasmid associated with EAggEC strains that encodes the genes for adherence and fimbriae. The sensitivity of the gene probe was $93 \%$ and the specificity $98 \%$ for detecting EAggEC isolates and is potentially useful for diagnostic and epidemiological studies.
\end{abstract}

\section{Introduction}

Escherichia coli strains that cause diarrhoea in man are separated into five categories on the basis of their pathogenic mechanisms: enterotoxigenic (ETEC), enteropathogenic (EPEC), enteroinvasive (EIEC), enterohaemorrhagic (EHEC) and enteroadherent (EAEC). ${ }^{1}$ The last category, EAEC, has been defined on the basis of the adherent properties and phenotypic characteristics exhibited when the bacteria are incubated with HEp-2 or HeLa cell lines. They are called diffuse-adherent (DA) when the bacteria cover the cell surface uniformly and aggregative adherent (AA) when clumps of bacteria with a characteristic "stacked brick" appearance are found on the surface of HEp-2 cells. $^{2}$ The phenotypic characteristics are sometimes difficult to discern by this procedure. Unfortunately, there are as yet no other means of identifying these groups. Some strains of $E$. coli show localised adherence (LA) on tissue culture cells, but these have been found generally to belong to the EPEC category. While it has been proposed that some DA $E$. coli strains are diarrhoeagenic, other strains have not been shown to be consistently pathogenic in epidemiological ${ }^{3,4}$ or challenge studies. ${ }^{5}$ AA E. coli (EAggEC) have been isolated recently from infants and children suffering from persistent diarrhoea in several countries world-wide $^{3.6-8}$ This form of diarrhoea, where the

Received 8 Nov. 1993; revised version accepted 17 June 1994.

* Correspondence should be sent to Dr C. Debroy, Supelco Inc., Supelco Park, Bellefonte, PA 16823, USA. episode continues for more than 14 days, ${ }^{6,9}$ seems to account for disproportionately high diarrhoea-related morbidity and mortality among children in the developing world. ${ }^{10-12}$

The EAggEC isolates carry a $60-\mathrm{MDa}$ plasmid which is required for the expression of the aggregative phenotype ${ }^{13}$ The adhesion properties of many of the EAggEC strains have been attributed to the mannoseresistant fimbriae that mediate adhesion of the bacteria to rabbit mucosa. ${ }^{14}$ Recently, electronmicroscopy of colonic mucosa demonstrated that the adhesion of the EAggEC strains in infected human patients is also mediated by fimbriae. ${ }^{15}$ The $60-\mathrm{MDa}$ plasmid for the prototype EAggEC culture 17-2, has been shown to encode for bundle-forming fimbriae called aggregative adherence fimbriae $(\mathrm{AAF} / 1)^{16}$ that manifest $\mathrm{AA}$ properties. AAF $/ 1$ is also associated with haemagglutination of human erythrocytes. Further subcloning of the region encoding the aaf-1 gene indicated that the expression of the fimbriae requires two separate regions of the plasmid. ${ }^{17}$ The $60-\mathrm{MDa}$ plasmid also encodes the gene for a heat-stable, low mol. wt toxin called EAST. ${ }^{18}$ The role of the toxin in the virulence of these bacteria has not yet been elucidated. A $1-\mathrm{kb}$ gene probe (pCVD 432) was constructed from the $60-\mathrm{MDa}$ plasmid associated with the representative strain (172) isolated from a Chilean patient. ${ }^{19}$ The probe was found to be $c .89 \%$ sensitive for detecting EAggEC isolates from Chile. However, recently the probe was found to be $<50 \%$ sensitive for detecting EAggEC isolates from Thailand. ${ }^{20}$

In this report, the construction of a gene probe from 
the 60-MDA plasmid associated with one of the prototype EAggEC strains is described.

\section{Materials and methods}

\section{Bacterial strains and serotyping}

The EAggEC strains used in this study were from the faeces of infants and children suffering from persistent diarrhoea in India and were isolated after overnight culture on MacConkey and deoxycholate citrate agar plates and in selenite enrichment broth at $37^{\circ} \mathrm{C}$. The isolates were identified by standard methods. $^{21}$ The isolates from Mexico were kindly provided by Dr J. Mathewson, University of Texas Medical School, USA, and those from Brazil by Dr R. Guerrant, University of Virginia, USA. Strain 17-2 and gene probe pCVD 432 were obtained from $\mathrm{Dr}$ J. B. Kaper, Center for Vaccine Development (CVD), MD, USA. Clone pJPN 37 was obtained from Dr J. Nataro, CVD. The other $E$. coli strains were from the E. coli Reference Center at Pennsylvania State University, USA. The $\mathrm{O}: \mathrm{H}$ serotypes of diarrhoeagenic EAggEC isolates were determined by the method of Ørskov et al $;^{22} 200 \mathrm{O}$-type and $52 \mathrm{H}$-type antisera were used.

\section{Adhesion assay}

The isolates were tested for their adherence properties with HEp-2 cells. ${ }^{2}$ Briefly, bacteria grown overnight in Luria broth (LB) were incubated with a monolayer of HEp-2 cells for $3 \mathrm{~h}$ at $37^{\circ} \mathrm{C}$, washed and stained with Giemsa, and observed by light microscopy. The isolates that showed an aggregative adherence (AA) pattern were used for evaluating the sensitivity of the gene probe.

\section{Plasmid curing}

Plasmid DNA was cured from a representative strain (F03) with acridine orange (AO) or acriflavin (AF) ${ }^{23}$ Bacteria grown for $6 \mathrm{~h}$ in LB medium were diluted 50fold in LB medium containing AO $(0,8 \cdot 5,10$ and $15 \mu \mathrm{g} / \mathrm{ml})$ or $\mathrm{AF}(0,1,2,2 \cdot 5,3,4$ and $5 \mu \mathrm{g} / \mathrm{ml})$ and incubated at $37^{\circ} \mathrm{C}$ for $24 \mathrm{~h}$ without shaking. The cultures were diluted $2 \times 10^{5}$ times with saline and assayed for viable cells on nutrient agar (NA). Fifty colonies were picked from representative plates inoculated from LB cultures containing different concentrations of $\mathrm{AO}$ and $\mathrm{AF}$ and streaked on NA plates with and without antibiotics-ampicillin $100 \mathrm{mg} / \mathrm{L}$, tetracycline $20 \mathrm{mg} / \mathrm{L}$, chloramphenicol $30 \mathrm{mg} / \mathrm{L}$, amoxycillin $30 \mathrm{mg} / \mathrm{L}$ and streptomycin $30 \mathrm{mg} / \mathrm{L}$. Those that were sensitive to antibiotics were presumed to have lost the plasmids and they were checked for the presence of plasmids by the method of Birnboim and Doly. ${ }^{24}$

\section{Construction of the gene probe}

Plasmid DNA (60-65 MDa) was extracted from an overnight culture of a representative EAggEC strain (F03-1) by an alkaline lysis procedure. ${ }^{24}$ The DNA was digested with restriction endonucleases $E c o \mathrm{R} 1$ or Bam $\mathrm{Hl}$ or Pst 1 according to manufacturer's protocol. The digested fragments were ligated to the corresponding site in a pUC19 vector sample digested with the respective enzymes. DH5 $\alpha$ cells were transformed with the recombinant plasmid according to the protocol supplied by Bethesda Research Laboratory (BRL), MD, USA. The DH $5 \alpha$ transformants were grown overnight on LB agar plates containing X-Gal (5-bromo-4-chloro-3-indolyl- $\beta$-D-galactoside) and ampicillin $100 \mathrm{mg} / \mathrm{L}^{25}$ Plasmids were isolated from $c$. 300 white colonies representing the clones with inserts, digested with restriction endonucleases and electrophoresed on agarose $0.7 \%$ gels. The sizes of the DNA inserts were determined by comparing the bands with standard HindIII digested lambda DNA mol.wt markers from BRL. The inserts were used as candidate probes after radiolabelling with $\left[{ }^{32} \mathrm{P}\right] \mathrm{dATP}$ by nick translation according to the protocol supplied by the manufacturer (BRL). The specific activities of the probes (pVAP and pCVD 432) used for hybridisation were $c .10^{6} \mathrm{dpm}$ (disintegrations $/ \mathrm{min}$ ).

\section{Colony blot hybridisation}

$E$. coli isolates were grown on LB agar and the colonies were transferred to Whatman 541 filter papers. The colonies were lysed by laying the filters on $3 \mathrm{MM}$ filters soaked with lysing solution $(0.5 \mathrm{~N} \mathrm{NaOH}$, $1.5 \mathrm{M} \mathrm{NaCl}$ ) in a petri dish. ${ }^{26}$ The dishes were heated at $100^{\circ} \mathrm{C}$ for $5 \mathrm{~min}$. The filters were then neutralised (1 $\mathrm{M}$ Tris- $\mathrm{HCl} \mathrm{pH} \mathrm{7,2} \mathrm{M} \mathrm{NaCl}$ ) for $5 \mathrm{~min}$. The filter papers were dried in air and hybridised with ${ }^{32} \mathrm{P}$ labelled DNA probes. The filter papers were placed in plastic bags containing the hybridisation solution(formamide $50 \%, 10 \times \mathrm{SSC}(1.5 \mathrm{M} \mathrm{NaCl}, 0.15 \mathrm{~m}$ sodium citrate), SDS $0 \cdot 1 \%$, Ficoll $0 \cdot 1 \%$, polyvinylpyrrolidone $0 \cdot 1 \%$, bovine serum albumin $0 \cdot 1 \%, 2 \mathrm{~mm}$ EDTA-and the radioactive gene probe was denatured by heating at $100^{\circ} \mathrm{C}$ for $5 \mathrm{~min}$. The filters were incubated at $37^{\circ} \mathrm{C}$ as described by Sambrook et al. ${ }^{25}$ The filters were washed three times with $50 \mathrm{ml}$ of $0.2 \times \mathrm{SSC}$ and SDS $0.1 \%$, each time at $37^{\circ} \mathrm{C}$. The probe-positive colonies were detected by exposing the filter paper to X-ray film; they appeared as dark spots on the film.

\section{Transmission electronmicroscopy (TEM)}

Bacteria grown on nutrient agar overnight at $37^{\circ} \mathrm{C}$ were washed three times with phosphate-buffered saline (PBS) and resuspended in distilled water. They were stained with ammonium molybdate $(\mathrm{pH} 7) 2 \%$ and bacitracin $150 \mathrm{mg} / \mathrm{L} .{ }^{15}$ The suspension was applied to carbon-coated grids, the excess fluid was removed, and the grid was examined in a Jeol 1200 EXII Transmission electronmicroscope. 


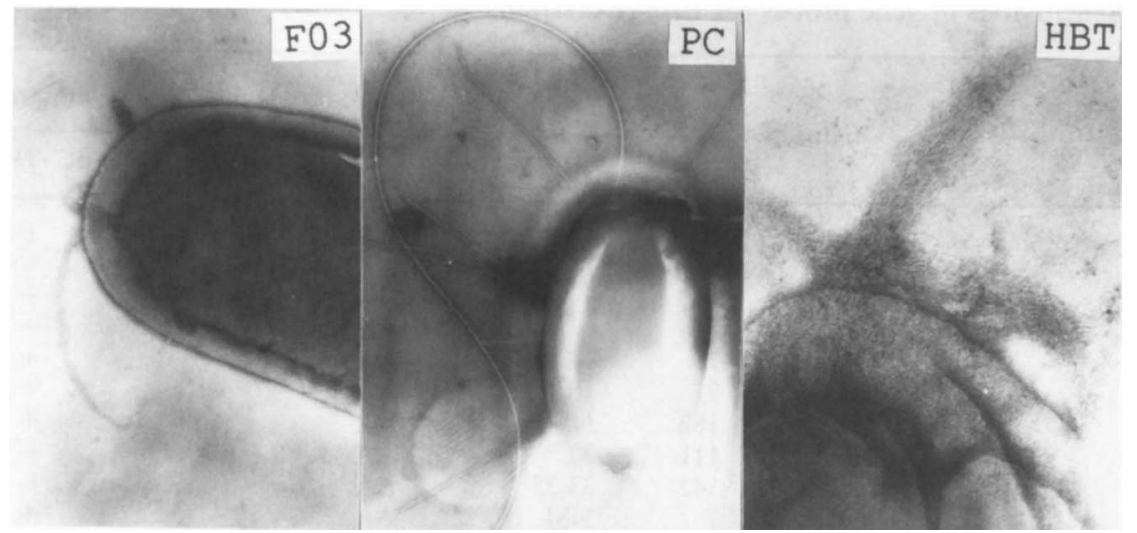

Figure. Electronmicrographs of wild-type and transformed EAggEC strains: prototypic strain (FO3) showing a fimbria $(\times 100000)$; plassmid-cured strain $(\mathrm{PC})$ showing a flagellum and fimbriae $(\times 50000)$; non-pathogenic strain HB101, transformed with the 60-MDa plasmid (HBT) showing fimbriae in the form of fimbrillar bundles $(\times 250000)$.

\section{Results}

EAggEC strains from patients suffering from persistent diarrhoea were obtained from four countriesBrazil, Mexico, Chile and India. All the isolates exhibited the aggregative phenotype when incubated with the HEp- 2 cell line. The O serotypes of the isolates varied considerably but $\mathrm{O} 78$ (six isolates) was the commonest (table I); 31 different serotypes were recorded and 17 isolates did not appear to belong to any known $\mathrm{O}$ serotype and were designed as giving a negative reaction. The $\mathrm{H}$ serotype of isolates was mostly non-modal and 16 isolates gave negative reactions with all the $\mathrm{H}$ antisera. Plasmid profiles of the EAggEC strains from India showed a common 60-MDa plasmid in addition to one or more plasmids of 4-22 kb (data not shown). The major characteristic of EAggEC, the AA phenotype, was considered an important factor for gene probe development. Therefore, attempts were made to identify the location of the AA determinant before constructing the gene probe. The prototype strain FO3, isolated from an infant with diarrhoea in India, harboured two plasmids (60 MDa and $4 \mathrm{~kb}$ ). Curing the $4-\mathrm{kb}$ plasmid did not affect AA, whereas the bacteria that lost both the 4-kb and 60MDa plasmids (PC) also lost AA properties. When a non-pathogenic $E$. coli strain, HB101, was transformed with the 60-MDa plasmid from FO3, the transformed bacteria (HBT) exhibited the AA phenotype. These results indicated clearly that the $60-\mathrm{MDa}$ plasmid conferred the AA phenotype to EAggEC strains from the Indian subcontinent.

The correlation of the adherence properties of the bacteria with the development of fimbriae was also examined. The wild-type strain (F03), the transformed culture (HBT) and the plasmid-cured strain (PC) were observed by transmission electronmicroscopy (TEM). Fimbriae were observed in the wild-type strain F03 and the transformed culture HBT, whereas PC showed long flagella and fimbriae (figure). HB101, the host for the transformation experiment, did not exhibit any fimbriae (data not shown). The genes for fimbriae formation were encoded by the $60-\mathrm{MDa}$ plasmid which further supported the construction of a gene probe from the plasmid DNA.

Of 300 clones constructed from the plasmid DNA, 20 with inserts of $0.5-1 \mathrm{~kb}$ were selected as candidate probes. Each one was tested by colony hybridisation with EAggEC and other diarrhoeagenic strains. Three of the $E c o$ R 1 fragments tested as probes exhibited very little specificity for EAggEC strains. The other fragments derived by digesting the DNA with $\mathrm{BamH} 1$ and Pst 1 exhibited only moderate sensitivity (25-62\%) for detecting EAggEC strains. Only one of the clones (pVAP), with a 730-bp EcoR1 insert, exhibited very high sensitivity as well as specificity for EAggEC isolates from India, Brazil, Mexico and Chile and, therefore, was selected as the candidate probe. Probe pVAP, under highly stringent conditions of hybridisation, hybridised with 57 of 61 isolates $(93 \%$ sensitivity) (table I). Under similar optimal hybridisation conditions, probe pCVD $432,{ }^{19}$ currently available for detecting EAggEC, hybridised with only 43 of the 61 isolates ( $70 \%$ sensitivity) (table I). Both probes, pVAP and pCVD 432, hybridised with prototypic strains FO3 and 17-2, used as positive controls, but not with strains $\mathrm{HB} 101$ and $\mathrm{PC}$ that served as negative controls. Probes pVAP and pCVD 432, despite being constructed from the 60-MDa plasmid, did not hybridise with each other and, therefore, do not share complementary DNA sequences.

Probe pVAP was evaluated against isolates belonging to EPEC, ETEC, EHEC and EAEC (DA and LA) categories of diarrhoeagenic $E$. coli from 20 different countries world-wide. Of the 90 isolates tested, only two EPEC strains, (2708-78 and 2394-80) of serotype $\mathrm{O} 111: \mathrm{H} 21$, hybridised with pVAP. The specificity of probe pVAP was also evaluated against other diarrhoeagenic bacteria (table II) such as $\mathrm{Sal}$ monella, Yersinia, Shigella, Klebsiella, Vibrio, Pseudomonas and Citrobacter spp. None of the 14 strains tested exhibited any complementarity with pVAP. Of 104 strains tested for specificity, only two cultures reacted positivity with pVAP. The specificity of the probe was thus calculated to be $c .98 \%$. 
Table I. Sensitivities of gene probes for EAggEC strains

\begin{tabular}{|c|c|c|c|c|c|c|}
\hline \multirow{2}{*}{$\begin{array}{c}\text { Isolate } \\
\text { no. }\end{array}$} & \multirow{2}{*}{ Origin } & \multicolumn{2}{|c|}{ Serotype } & \multirow{2}{*}{$\begin{array}{c}\text { HEp-2 } \\
\text { assay }\end{array}$} & \multicolumn{2}{|c|}{ Hybridisation with probe } \\
\hline & & $\mathrm{O}$ & $\mathrm{H}$ & & pVAP & pCVD432 \\
\hline FO1 & India & 17 & 6 & AA & + & + \\
\hline $\mathrm{FO} 2$ & India & 51 & 11 & $\mathrm{AA}$ & + & + \\
\hline FO3 & India & 4 & 7 & AA & + & + \\
\hline FO4 & India & 51 & - & AA & + & + \\
\hline FO5 & India & 75 & NM & AA & - & - \\
\hline FO6 & India & 77 & 18 & AA & + & + \\
\hline FO7 & India & 162 & NM & AA & + & + \\
\hline HO8 & India & 111 & 32 & $\mathrm{AA}$ & + & - \\
\hline HO9 & India & 142 & 33,35 & $\mathrm{AA}$ & - & - \\
\hline $\mathrm{HO} 10$ & India & 7 & NM & AA & + & + \\
\hline HO11 & India & 6 & - & $\mathrm{AA}$ & + & - \\
\hline HO12 & India & - & 32 & AA & + & + \\
\hline $\mathrm{HO} 13$ & India & 68,73 & NM & $\mathrm{AA}$ & + & + \\
\hline HO14 & India & - & NM & AA & + & - \\
\hline HO15 & India & - & - & AA & + & + \\
\hline HO16 & India & 78 & - & AA & + & + \\
\hline HO17 & India & 78 & - & AA & + & + \\
\hline HO18 & India & 85 & - & $\mathrm{AA}$ & + & + \\
\hline $\mathrm{HOl9}$ & India & 7 & NM & $\mathrm{AA}$ & + & + \\
\hline $\mathrm{HO} 20$ & India & - & NM & $\mathrm{AA}$ & + & + \\
\hline $17-2$ & Chile & 3 & 42 & AA & + & + \\
\hline PDAS21-1 & Brazil & - & 10 & $\mathrm{AA}$ & + & + \\
\hline PDAS23-1 & Brazil & 78 & NM & AA & + & + \\
\hline PDAS34-5 & Brazil & - & NM & $\mathrm{AA}$ & + & + \\
\hline PDAS46-1 & Brazil & 68 & $\mathrm{NM}$ & $\mathrm{AA}$ & + & + \\
\hline PDAS48-1 & Brazil & 15 & NM & AA & + & + \\
\hline PDAS52-5 & Brazil & - & - & $\mathrm{AA}$ & + & + \\
\hline PDAS71-1 & Brazil & 20 & $\mathrm{NM}$ & $\mathrm{AA}$ & + & - \\
\hline PDAS113-2 & Brazil & 86 & - & AA & + & + \\
\hline PDAS116-1 & Brazil & - & - & $\mathrm{AA}$ & + & + \\
\hline PDAS121-1 & Brazil & - & NM & $\mathrm{AA}$ & - & - \\
\hline PDAS131-1 & Brazil & 91 & NM & $\mathrm{AA}$ & + & + \\
\hline PDAS150-1 & Brazil & 81 & - & $\mathrm{AA}$ & - & - \\
\hline PDAS160-1 & Brazil & 44 & NM & $\mathrm{AA}$ & + & + \\
\hline PDAS $174-1$ & Brazil & - & $\mathrm{NM}$ & $\mathrm{AA}$ & + & + \\
\hline PDAS175-1 & Brazil & 5 & 10 & AA & + & - \\
\hline PDAS176-1 & Brazil & - & NM & $\mathrm{AA}$ & + & + \\
\hline PDAS178-3 & Brazil & - & - & $\mathrm{AA}$ & + & + \\
\hline PDAS188-1 & Brazil & 21 & $\mathrm{NM}$ & $\mathrm{AA}$ & + & - \\
\hline PDAS98-1 & Brazil & 11 & $\mathrm{NM}$ & $\mathrm{AA}$ & + & + \\
\hline JM 24 & Mexico & 15 & 1 & $\mathrm{AA}$ & + & + \\
\hline JM 32 & Mexico & - & 10 & $\mathrm{AA}$ & + & + \\
\hline JM 45 & Mexico & 86 & 2 & $\mathrm{AA}$ & + & + \\
\hline JM 70 & Mexico & 92,78 & - & AA & + & + \\
\hline JM 71 & Mexico & 25 & NM & $\mathrm{AA}$ & + & - \\
\hline JM 72 & Mexico & 85 & NM & AA & + & - \\
\hline JM 77 & Mexico & 15 & - & AA & + & + \\
\hline JM 162 & Mexico & 52 & 27 & AA & + & + \\
\hline JM 190 & Mexico & 17 & 18 & $\mathrm{AA}$ & + & - \\
\hline JM 215 & Mexico & 92,78 & 33,35 & AA & + & + \\
\hline JM 221 & Mexico & - & - & $\mathrm{AA}$ & + & + \\
\hline JM 314 & Mexico & 133 & NM & AA & + & - \\
\hline JM 315 & Mexico & 151 & 49 & AA & + & + \\
\hline JM 323 & Mexico & - & 32 & AA & + & + \\
\hline JM 333 & Mexico & 113 & 21 & $\mathrm{AA}$ & + & - \\
\hline JM 366 & Mexico & 36 & - & AA & + & - \\
\hline JM 389 & Mexico & 78 & NM & $\mathrm{AA}$ & + & + \\
\hline JM 392 & Mexico & - & NM & $\mathrm{AA}$ & + & + \\
\hline JM 398 & Mexico & - & - & AA & + & + \\
\hline JM 417 & Mexico & 59 & NM & $\mathrm{AA}$ & + & - \\
\hline JM 459 & Mexico & 59 & NM & AA & + & - \\
\hline FO3-1 (+ ve control) & & - & - & AA & + & + \\
\hline PC (-ve control) & & - & - & - & - & - \\
\hline HBiol (-ve control) & & - & - & - & - & - \\
\hline pVAP & & - & - & - & + & - \\
\hline pCVD432 & & - & - & - & - & + \\
\hline
\end{tabular}

$\mathrm{O}$ and $\mathrm{H}$ serotypes: - , negative reaction; multiple numbers, multiple reaction; $\mathrm{NM}$, nonmotile. AA : aggregative adherence. 
Table II. Specificity of the gene probe with other bacteria; none hybridised with pVAP

\begin{tabular}{llll}
\hline Strain & $\begin{array}{c}\text { Isolate } \\
\text { no. }\end{array}$ & Source & Origin \\
\hline Salmonella typhi & 4050 & Human & India \\
S. typhi & 3935 & Human & India \\
Shigella flexneri & 456 II & Human & India \\
Sh. flexneri & 27188 & Human & India \\
Klebsiella spp. & H850 A & Human & India \\
Klebsiella spp. & H891 I & Human & India \\
Vibrio cholerae & 460 I & Human & India \\
V. cholerae & 433 I & Human & India \\
S. typhimurium & 688 II & Human & India \\
S. typhimurium & 658 III & Human & India \\
S. typhimurium & 638 III & Human & India \\
Yersinia spp. & 43 I & Human & India \\
Pseudomonas aeruginosa & 462 & Human & India \\
Citrobacter spp. & 632 & Human & India \\
& & & \\
\hline
\end{tabular}

\section{Discussion}

Diarrhoeal diseases caused by $E$. coli remain a major public health problem world-wide. EAggEC strains that cause persistent diarrhoea have been recognised increasingly as an important problem in developing countries. ${ }^{6}{ }^{, 27}$ With the present population of the world travelling more than ever before, attention should be given to measures to detect and control this group of enteric pathogens. The development of effective gene probes that will distinguish EAggEC from other diarrhoeagenic $E$. coli strains that are common in the developing world is important for patient management and for controlling the disease. As reports for detection of EAggEC strains among patients with diarrhoea are coming to light, the diversity in genotypic characteristics of the organisms is also becoming more apparent. This is reflected by the fact that the only gene probe presently available is ineffective in detecting all the different genotypes of this group of bacteria. ${ }^{20}$ Because of the difficulty in recognising EAggEC isolates, there is an urgent need for establishing additional methods of detection in order to comprehend the epidemiological significance and global importance of this group of pathogens as diarrhoeal agents. This will assist in identifying the risk factors, modes of transmission and the source and spectrum of clinical illnesses.

Gene probes have proved to be very effective diagnostic tools for identifying other diarrhoeagenic E. coli such as ETEC, EPEC, EHEC and EIEC. ${ }^{28-31}$

\section{References}

1. Donnenberg MS, Kaper JB. Enteropathogenic Escherichia coli. Infect Immun 1992; 60: 3953-3961.

2. Cravioto A, Gross RJ, Scotland SM et al. An adhesive factor found in strains of Escherichia coli belonging to the traditional enteropathogenic serotypes. Curr Microbiol $1979 ; 3$ : 95-99.
The gene probes developed for stable toxins (St-Ap, St-B), labile toxin (LT), Shiga-like toxins I and II, the attaching and effacing gene (eae) or the EAF factor that are employed to identify ETEC, EHEC and EIEC and EPEC strains did not hybridise with any of the EAggEC strains in the present investigation (data not shown). Therefore, this group is distinct from the other categories of diarrhoeagenic E. coli. The EAggEC isolates from India, Brazil and Mexico, when serotyped with antisera to $200 \mathrm{O}$-types and $52 \mathrm{H}$ types, exhibited wide diversity (table I) and could not be categorised or grouped on the basis of serotype. Seventeen stains out of 61 did not react with any of the $O$ antisera and 16 strains did not react with any of the $\mathrm{H}$ antisera. This indicated that the $\mathrm{O}$ and $\mathrm{H}$ antigens of some of the EAggEC strains were unique and have not been observed previously.

The number of plasmids associated with these strains varied considerably. Whereas some of the strains exhibited only one plasmid, others harboured three or four. The plasmids seem to be responsible for inducing expression in non-pathogenic strain HB101 and conferring resistance to antimicrobial agents. Whereas PC was sensitive to all antibiotics tested, all the wild type EAggEC strains from India were resistant to penicillin (10 units), bacitracin (10 units) and streptomycin (100 units) and $95 \%$ were resistant to tetracycline $(30 \mathrm{mg} / \mathrm{L})$ and erythromycin $(15 \mathrm{~m} / \mathrm{L})$ (data not shown).

Gene probe pVAP, although developed from the 60-MDa plasmid, did not have any sequence complementary to the aggregative adherence fimbriae gene $(\text { aaf }-1)^{17}$ as was evident from a hybridisation experiment with clone pJPN-437 that encodes the aaf-1 region. The probe appears to be from a different region of the plasmid. Although the specificity of the probe was found to be $98 \%$, it hybridised with two EPEC strains of serotype 0111:H21. Scotland et al ${ }^{32}$ also found that the gene probe pCVD 432 hybridised with EPEC strains of serotype O111ab:H21 that exhibited aggregative adherence. Several strains from Mexico that were considered to be DA before AA was recognised as a distinct pattern, were found to hybridise with pVAP and pCVD 432 and exhibited AA properties. Therefore, more comprehensive studies are required to determine the correlation of this newly discovered pathogen with the other categories of diarrhoeagenic E. coli.

This work was supported by the Indo-U.S. Vaccine Action Programme, National Institutes of Health grant no. RO3 AI3225302 .

3. Giron JA, Jones T, Millan-Velasco F et al. Diffuse-adhering Escherichia coli (DAEC) as a putative cause of diarrhea in Mayan children in Mexico. J Infect Dis 1991 ; 163: 507-513.

4. Gomes TAT, Blake PA, Trabulsi LR. Prevalence of Escherichia coli strains with localized, diffuse, and aggregative adherence to HeLa cells in infants with diarrhea and matched controls. J Clin Microbiol 1989; 27 : 266-269. 
5. Tacket CO, Moseley SL, Kay B, Losonsky G, Levine MM Challenge studies in volunteers using Escherichia coli strains with diffuse adherence to HEp-2 cells. $J$ Infect Dis 1990; 162: 550-552.

6. Bhan MK, Arora NK, Ghai OP, Ramachandran K, Khoshoo $\mathrm{V}$, Bhandari N. Major factors in diarrhoea related mortality among rural children. Indian $J$ Med Res 1986; 83 9-12.

7. Nataro JP, Kaper JB, Robins-Browne $R$, Prado V, Vial P, Levine MM. Patterns of adherence of diarrheagenic Escherichia coli to HEp-2 cells. Pediatr Infect Dis J 1987; 6: 829-831.

8. Wanke CA, Schorling JB, Barrett LJ, Desouza MA, Guerrant RL. Potential role of adherence traits of Escherichia coli in persistent diarrhea in an urban Brazilian slum. Pediatr Infect Dis $J$ 1991; 10: 746-751.

9. Bhan MK, Raj P, Levine MM et al. Enteroaggregative Escherichia coli associated with persistent diarrhea in a cohort of rural children in India. J Infect Dis 1989; 159: 1061-1064

10. Claeson M, Merson MH. Global progress in the control of diarrheal diseases. Pediatr Infect Dis J 1990; 9: 345-355.

11. USAID. Child survival 1985-1990: a sixth report to Congress on the USAID program. 1991. Washington, D.C., US Agency for International Development.

12. World Health Organization, Diarrhoeal Disease Control Programme. Persistent diarrhoea in developing countries. Memorandum from a WHO meeting. Bull World Health Organ 1988; 66: 709-717.

13. Nataro JP, Scaletsky ICA, Kaper JB, Levine MM, Trabulsi LR. Plasmid-mediated factors conferring diffuse and localized adherence of enteropathogenic Escherichia coli. Infect Immun $1985 ;$ 48: 378-383.

14. Vial PA, Robins-Browne R, Lior $\mathbf{H}$ et al. Characterization of Enteroadherent-aggregative Escherichia coli, a putative agent of diarrheal disease. $J$ Infect Dis 1988; 158: 70-79.

15. Knutton S, Shaw RK, Bhan MK et al. Ability of enteroaggregative Escherichia coli strains to adhere in vitro to human intestinal mucosa. Infect Immun 1992; 60: 2083-2091.

16. Nataro JP, Deng Y, Meneval DR, German AL, Martin WC, Levine MM. Aggregative adherence fimbriae I of enteroaggregative Escherichia coli mediate adherence to HEp-2 cells and hemagglutination of human erythrocytes. Infect Immun 1992; 60: 2297-2304.

17. Nataro JP, Yikang D, Giron JA, Savarino SJ, Kothary MH, Hall R. Aggregative adherence fimbriae 1 expression in enteroaggregative Escherichia coli requires two unlinked plasmid regions. Infect Immun 1993; 61 : 1126-1131.

18. Savarino SJ, Fasano A, Robertson DC, Levine MM. Enteroaggregative Escherichia coli elaborate a heat-stable entero- toxin demonstrable in in vitro intestinal model. $J$ Clin Invest $1991 ; 87: 1450-1455$

19. Baudry B, Savarino SJ, Vial P, Kaper JB, Levine MM. A sensitive and specific DNA probe to identify enteroaggregative Escherichia coli, a recently discovered diarrheal pathogen. J Infect Dis 1990; 161: 1249-1251.

20. Echeverria $P$, Serichantalerg $O$, Changchawalit $S$ et al. Tissue culture-adherent Escherichia coli in infantile diarrhea. $J$ Infect Dis 1992; 165: 141-143.

21. World Health Organization. Manual for laboratory investigations of acute enteric infections. Geneva, WHO. 1983.

22. Orskov I, Orskov F, Jann B, Jann K. Serology, chemistry and genetics of $\mathrm{O}$ and $\mathrm{K}$ antigens of Escherichia coli. Bacteriol Rev 1977; 41: 667-710.

23. Watanabe T, Fukasawa T. Episome-mediated transfer of drug resistance in Enterobacteriaceae. II. Elimination of resistance factors with acridine dyes. $J$ Bacteriol 1961; 81: $679-683$.

24. Birnboim HC, Doly J. A rapid alkaline extraction procedure for screening recombinant plasmid DNA. Nucleic Acids Res $1979 ; 7: 1513-1523$

25. Sambrook J, Fritsch, EF, Maniatis T. Molecular cloning, a laboratory manual, 2nd edn. Cold Spring Harbor, New York, Cold Spring Harbor Laboratory. 1989.

26. Maas R. An improved colony hybridization method with significantly increased sensitivity for detection of single genes. Plasmid 1983; 10: 296-298.

27. McAuliffe JF, Shields DS, deSouza MA, Sakell J, Schorling J, Guerrant RL. Prolonged and recurring diarrhea in the northeast of Brazil: examination of cases from a community-based study. $J$ Pediatr Gastroenterol Nutr $1986 ; 5: 902-906$.

28. Lanata CF, Kaper JB, Baldini MM, Black RE, Levine MM. Sensitivity and specificity of DNA probes with the stool blot technique for detection of Escherichia coli enterotoxins. J Infect Dis 1985; 152: $1087-1090$.

29. Levine MM, Xu J, Kaper JB et al. A DNA probe to identify enterohemorrhagic Escherichia coli of O157:H7 and other serotypes that cause hemorrhagic colitis and hemolytic uremic syndrome. J Infect Dis 1987; 156: 175-182.

30. Levine MM, Prado V, Robins-Browne $\mathrm{R}$ et al. Use of DNA probes and HEp-2 cell adherence assay to detect diarrheagenic Escherichia coli. J Infect Dis 1988; 158: 224-228.

31. Moseley SL, Echeverria $\mathbf{P}$, Seriwantana $\mathbf{J}$ et al. Identification of enterotoxigenic Escherichia coli by colony hybridization with three enterotoxin gene probes. J Infect Dis 1982;145: 863-869.

32. Scotland SM, Smith HR, Said B, Willshaw GA, Cheasty T, Rowe B. Identification of enteropathogenic Escherichia coli isolated in Britain as enteroaggregative or as members of a subclass of attaching- and- effacing $E$. coli not hybridising with the EPEC adherence-factor probe. $J \mathrm{Med}$ Microbiol 1991; 35: 278-283. 